Research Article

\title{
First-Principles Study on Adsorption and Decomposition of NO $x$ on Mo (110) Surface
}

\author{
Yunmi Huang $\mathbb{D}^{1,2}$ Haijun Luo, ${ }^{1,2}$ and Changkun Dong ${ }^{2}$ \\ ${ }^{1}$ College of Mathematics and Physics, Wenzhou University, Wenzhou 325035, China \\ ${ }^{2}$ Wenzhou Key Laboratory of Micro-Nano Optoelectronic Devices, Wenzhou University, Wenzhou 325035, China \\ Correspondence should be addressed to Yunmi Huang; huangym@wzu.edu.cn
}

Received 3 September 2021; Revised 22 November 2021; Accepted 14 December 2021; Published 30 December 2021

Academic Editor: Giuseppe Pellicane

Copyright ( 2021 Yunmi Huang et al. This is an open access article distributed under the Creative Commons Attribution License, which permits unrestricted use, distribution, and reproduction in any medium, provided the original work is properly cited.

Based on the density functional theory, the adsorption and decomposition of $\mathrm{NO}_{x}(x=1,2)$ on Mo $(110)$ surface are studied with first-principles calculations. Results show that the stable structures of $\mathrm{NO}_{2} / \mathrm{Mo}(110)$ are $\mathrm{MoNO}_{2}\left(\mathrm{~T}, \mu^{1}-\mathrm{N}\right), \mathrm{MoNO}_{2}\left(\mathrm{H}, \mu^{3}-\mathrm{N}, \mathrm{O}\right.$, $\left.\mathrm{O}^{\prime}\right), \mathrm{MoNO}_{2}\left(\mathrm{~S}, \eta^{2}-\mathrm{O}, \mathrm{O}^{\prime}\right)$, and $\mathrm{MoNO}_{2}\left(\mathrm{~L}, \eta^{2}-\mathrm{O}, \mathrm{O}^{\prime}\right)$. The corresponding adsorption energies for the structures are $-3.83 \mathrm{eV}$, $-3.40 \mathrm{eV},-2.81 \mathrm{eV}$, and $-2.60 \mathrm{eV}$, respectively. Besides, the stable structures of NO/Mo (110) are MoNO $\left(\mathrm{H}, \mu^{1}-\mathrm{N}\right), \mathrm{MoNO}\left(\mathrm{H}, \mu^{2}-\right.$ $\mathrm{N}, \mathrm{O})$, and $\mathrm{MoNO}\left(\mathrm{H}, \eta^{1}-\mathrm{N}\right)$ with the corresponding adsorption energies of $-3.75 \mathrm{eV},-3.57 \mathrm{eV}$, and $-3.01 \mathrm{eV}$, respectively. $\mathrm{N}$ and $\mathrm{O}$ atoms are easily adsorbed at the hollow sites on $\mathrm{Mo}(110)$ surfaces, and their adsorption energies reach $-7.02 \mathrm{eV}$ and $-7.70 \mathrm{eV}$, respectively. The preferable decomposition process of $\mathrm{MoNO}_{2}\left(\mathrm{H}, \mu^{3}-\mathrm{N}, \mathrm{O}, \mathrm{O}^{\prime}\right)$ shows that the first and second deoxidation processes need to overcome energy barriers of $0.11 \mathrm{eV}$ and $0.64 \mathrm{eV}$, respectively. All these findings indicate that $\mathrm{NO}_{2}$ is relatively easy to dissociate on Mo (110) surface.

\section{Introduction}

$\mathrm{NO}_{x}(x=1,2)$ gas widely exists in the process of industrial exhaust and automobile exhaust emission. It is a major cause of air pollution. It does not only cause a series of environmental problems, such as photochemical pollution, ozone layer destruction, haze, and other pollution but also causes considerable harm to human health. In order to reduce the harm of $\mathrm{NO}_{x}$ to humans and the environment, the removal and conversion of $\mathrm{NO}_{x}$ (adsorption, decomposition, desorption, etc.) had always been a hot research topic. Presently, the mechanism of transition metal surface and $\mathrm{NO}_{x}$ reaction is a hot topic in both experimental and theoretical simulation [1-11].

Molybdenum (Mo) and Mo-based catalysts exhibit excellent catalytic activity in many industrial areas, such as hydrodenitrogenation (HDN) [12-14] and hydrodesulfurization (HDS) of hydrocarbons, hydrogen evolution reaction (HER) [15-17], Fischer-Tropsch (F-T) synthesis [18, 19], and solid oxide fuel cell (SOFC) $[20,21]$. Accordingly, a fundamental research focus on the interactions of nitrogen oxides with Mo and Mo-based surfaces is helpful to understand the reaction mechanism between them.

Some experimental studies research on the interaction between $\mathrm{NO}_{2}$ and well-defined surfaces of Pt (111) [22-24], $\mathrm{Ru}$ (100) [25], Rh (111) [26], Ag (111) [27-29], Pd (111) $[28,30]$, and $\mathrm{Au}(111)[31,32]$. The results show that the $\mathrm{NO}_{2}$ can be completely dissociated on $\mathrm{Rh}$ (111), $\mathrm{Pd}$ (111), Pt (111), $\mathrm{Ru}$ (100), and Ag (111), and it is adsorbed in the molecular form on $\mathrm{Au}$ (111). At the same time, these experiment results indicate that the interaction between $\mathrm{NO}_{2}$ and metal surface can be generated by $\mathrm{N}$ atom or $\mathrm{O}$ atom.

Using the technologies of electron stimulated desorption ion angular distribution (ESDIAD), electron energy loss spectroscopy (EELS), temperature-programmed desorption (TPD), and low energy electron diffraction (LEED), the researchers analyzed the $\mathrm{NO}_{2}$ [33], $\mathrm{NO}[34,35]$, and $\mathrm{N}_{2} \mathrm{O}$ [34] dissociative adsorption on Mo (100) and Mo (110). It indicates that $\mathrm{NO}_{2}$ is easy to decompose to adsorbed $\mathrm{NO}+\mathrm{O}$ at the temperature of $100 \sim 150 \mathrm{~K}$, while it is further decomposed into $\mathrm{N}_{2}$ and $\mathrm{O}$ at the temperature of $250 \mathrm{~K}$, 
showing Mo surface has the good catalytic ability for $\mathrm{NO}_{x}$ removal and conversion.

However, the theoretical calculations on the role of $\mathrm{NO}_{x}$ on transition metals surfaces and their alloys surfaces are still limited. Some basic problems in the experimental studies, such as the final adsorption structures and decomposition paths of $\mathrm{NO}_{x}$ on the surfaces of transition metals and their alloys, have not been fully understood. For such microscopic processes, the experimental tools are not feasible. The firstprinciples calculation based on the density functional theory as a powerful tool can be used to investigate the reaction mechanisms of $\mathrm{NO}_{x}$ with transition metals surfaces.

In this study, we report our findings about the adsorption and decomposition of $\mathrm{NO}_{x}$ on Mo (110) surface with first-principles calculations. The goal of this study is to find out the most possibly dissociative process and the most stable adsorption structure of $\mathrm{NO}_{x}$ on the $\mathrm{Mo}(110)$ surface.

\section{Computational Method}

The software used for the theoretical calculation is the Vienna ab initio simulation package (VASP) for total energy calculation based on the density functional theory [36-38]. The software package is a first-principles quantum mechanics and molecular dynamics composite package. It calculates the total energy and electronic structure with a plane wave as the basis function. All electron projector augmented wave (PAW) is used to deal with the interaction between ion real and valence electrons [39, 40]. This is because the paw method is more accurate than other pseudopotentials such as ultra-soft pseudopotential (USPP), so the paw pseudopotential provided by the VASP is used in this paper. A Methfessel-Paxton [41] electronic energy smearing of $0.2 \mathrm{eV}$ is used in the self-consistent calculations. For the exchange-correlation energy function, the Perdew-Burke-Enzerhoff (PBE) functional and generalized gradient approximation (GGA) is used. Spin polarization and the correction of dipole moment are considered in the calculation process [42].

The surface structure of Mo (110) is simulated by a slab normal to $Z$ direction. The repeated slab is composed of 7 layers of molybdenum (Mo) atoms, with 4 layers for the substrate in which the positions of Mo atoms are fixed. The other remaining 3 layers of Mo atoms can relax their positions to optimize the total energy of the system when other species of atoms or molecules are adsorbed on the outer surfaces of the layers. A vacuum region with a thickness larger than $10 \AA$ is inserted between the adjacent crystal layers to avoid interference between the crystal layers.

The periodic supercell $p(2 \times 2)$ of the system is used to calculate the adsorption of $\mathrm{NO}_{2}, \mathrm{NO}, \mathrm{N}$, and $\mathrm{O}$. The selfconsistent calculation is carried out according to the irreducible k-point automatically generated by the Monkhorst-Pack scheme [41]. To optimize the total energy of the whole system, k-point grid sizes of $(21 \times 21 \times 21)$ and $(4 \times 4 \times 1)$ are used alternatively. In the calculation, the cutoff energy of plane wave expansion is taken as $400 \mathrm{eV}$. By changing the sampling point density and cut-off energy in $\mathrm{K}$ space to test the convergence, these settings are sufficient to ensure the accuracy of the calculation.

There are four possible positions for the adsorption, namely top ( $\mathbf{T}$ for short), long bridge ( $\mathbf{L}$ for short), short bridge ( $\mathbf{S}$ for short), and hole ( $\mathbf{H}$ for short), as shown in Figure $1(\mathrm{a})$. The adsorption energy $E_{\text {ads }}$ is defined by the following expression

$$
E_{\text {ads }}=E_{(\text {absorbate+slab) }}-\left[E_{(\text {(slab })}+E_{(\text {adsorbate })}\right] .
$$

In the abovementioned expression, $E_{\text {(adsorbate }+ \text { slab) }}$ is the total energy of the optimized system with atoms adsorbed. $E_{\text {(slab) }}$ is the energy of the clean substrate surface and $E_{\text {(adsorbate) }}$ is for the gas phase adsorbed by the substrate. According to this definition, the adsorption energy is negative, which means that the process is exothermic.

The surface energy $\sigma$ is calculated using the equation

$$
\sigma=\frac{1}{A}\left[E_{\text {relax }}-\frac{1}{2}\left[E_{\text {unrelax }}+N E_{\text {bulk }}\right]\right] \text {, }
$$

where $E_{\text {relax }}, E_{\text {unrelax }}$, and $E_{\text {bulk }}$ represent the relaxed surface total energy, unrelaxed surface total energy, and the bulk total energy, respectively. A and $N$ represent the surface area of the slab and the number of atoms in the cell, respectively.

To study the decomposition of $\mathrm{NO}_{x}$, the climbing image nudged elastic band (CI-NEB) $[43,44]$ is used to search the transition state (TS). In this way, the path between the TSs is determined with the minimum energy. Practicably, eight images are set between the initial state (IS) and the final state (FS) for searching and locating the minimum energy paths (MEPs) of the decomposition reaction.

\section{Results and Discussion}

3.1. Bulk Mo and Clean Mo (110) Surface. Before studying the $\mathrm{NO}_{x}$ adsorption, let us study the structure of bulk Mo and clean Mo (110) surface at first. After the optimization in the calculation, the lattice parameter of the crystal molybdenum with body-centered cubic (BCC) structure is $3.146 \AA$, which is in good agreement with the experimental results $(\sim 3.15 \AA)$ $[45,46]$ and other calculated data $(\sim 3.16 \AA)[47,48]$. The $p$ $(2 \times 2)$-layer crystal model of 7 -layer Mo $(110)$ is used to simulate the clean Mo (110) surface shown in Figure 1(b). It is found that the relaxation between the first and second layers, noted by $\Delta d_{12}$, and the relaxation between the second and third layers, noted by $\Delta d_{23}$, are $-4.95 \%$ and $0.75 \%$, respectively. The relaxation between the third and fourth layers is calculated to be $\Delta d_{34}=0.26 \%$, which is too small compared to $\Delta d_{12}$ and $\Delta d_{23}$ and can be ignored. The surface energy $\sigma$ calculated for clean Mo (110) is $2.94 \mathrm{~J} / \mathrm{m}^{2}$ and the work function (W) is $4.57 \mathrm{eV}$, respectively. The data obtained above in this study are in good agreement with other reported values [49-52] and experimental measurements [53].

3.2. Gas-Phase $\mathrm{NO}_{2}$ and $\mathrm{NO}$ Molecules. The gas-phase $\mathrm{NO}_{2}$ and $\mathrm{NO}$ molecules are simulated. After optimization, the $\mathrm{N}-\mathrm{O}$ bond length of the NO molecule is $1.172 \AA$. The bond length of the $\mathrm{NO}_{2}$ molecule is $1.212 \AA$, and the angle of 


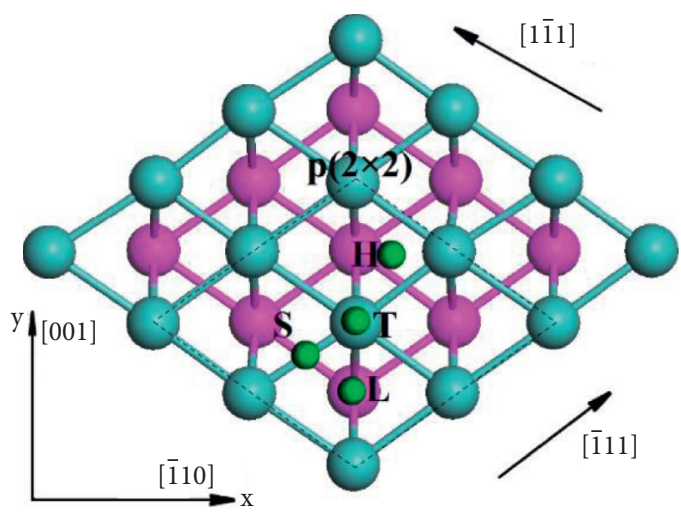

(a)

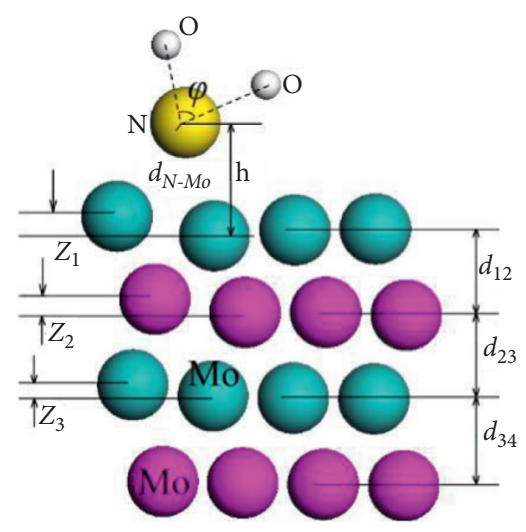

(b)

FIGURE 1: Model of Mo (110) surface (a) schematic diagram of possible adsorption coordination (b) schematic diagram of relaxation and other parameters.

$\mathrm{O}-\mathrm{NO}$ is $133.8^{\circ}$. Table 1 lists bond length, bond angle, asymmetric stretching $v_{\mathrm{a}}$, symmetric stretching $v_{\mathrm{s}}$, and bending frequencies $\nu_{\mathrm{b}}$. It can be seen that the calculated data in this paper are in good agreement with the experimental values.

3.3. $N$ and $O$ Atoms Adsorption on Mo (110) Surface. Generally, $\mathrm{NO}_{2}$ molecules are decomposed to be $\mathrm{NO}, \mathrm{N}$, and O. In order to study the possible decomposition and adsorption process of $\mathrm{NO}_{2}$ on the surface of $\mathrm{Mo}$ (110), it is necessary to understand many possible stable adsorption structures including $\mathrm{NO}_{2} / \mathrm{Mo}$ (110), NO/Mo (110), N/Mo (110), and O/Mo (110). As discussed above, the four different adsorption sites, namely, $\mathbf{T}, \mathbf{S}, \mathbf{L}$, and $\mathbf{H}$, are considered. The symbols $\eta$ and $\mu$ represent that the molecular plane of NO $x$ is perpendicular and parallel to the substrate, respectively. The following definitions are the same.

At the same time, because of the symmetry of the molecular structure, it is also necessary to consider the possibility of multiple placements of adsorbed molecules during research. As shown in Figure 2, five adsorbed modes of $\mathrm{NO}_{2}$ adsorption are considered. In this way, based on the detailed consideration of adsorption coordination and placement modes, all possible stable adsorption structures, including adsorption energies, stable adsorption sites, and adsorption geometries (bond length and bond angle) of NO, $\mathrm{N}$, and $\mathrm{O}$ on Mo (110), are finally obtained.

First, let us consider the adsorption of $\mathrm{N}$ and $\mathrm{O}$ atoms on the Mo (110) surface. Figure 3 and Table 2 show that there are four adsorption structures of $\mathrm{N}$ adsorption on Mo (110) surface, namely, $\operatorname{MoN}\left(\mathbf{H}, \mu^{1}-\mathrm{N}\right), \operatorname{MoN}\left(\mathbf{L}, \mu^{1}-\mathrm{N}\right), \operatorname{MoN}(\mathbf{S}$, $\left.\mu^{1}-\mathrm{N}\right)$, and $\operatorname{MoN}\left(\mathrm{T}, \eta^{1}-\mathrm{N}\right)$. The corresponding adsorption energies are $-7.02 \mathrm{eV},-6.98 \mathrm{eV},-6.16 \mathrm{eV}$, and $-4.68 \mathrm{eV}$, respectively. It is found that the structure of $\operatorname{MoN}\left(\mathbf{H}, \mu^{1}-\mathrm{N}\right)$ is the most stable, and $\operatorname{MoN}\left(\mathrm{T}, \eta^{1}-\mathrm{N}\right)$ is less than that of $\operatorname{MoN}\left(\mathbf{H}, \mu^{1}-\mathrm{N}\right)$. The structures of $\operatorname{MoN}\left(\mathbf{H}, \mu^{1}-\mathrm{N}\right)$ and $\mathrm{MoN}$ $\left(\mathbf{L}, \mu^{1}-\mathrm{N}\right)$ have the shortest average distances ( $h$ in Table 2$)$ between the $\mathrm{N}$ atom and substrate. It can be concluded that, the closer the distance between the $\mathrm{N}$ atom and substrate, the stronger the binding.
TABLE 1: The structural parameters and vibrational frequencies of gas-phase $\mathrm{NO}_{2}$ and $\mathrm{NO}$ molecules.

\begin{tabular}{lcccc}
\hline & \multicolumn{2}{c}{$\mathrm{NO}_{2}$} & \multicolumn{2}{c}{$\mathrm{NO}$} \\
& $\mathrm{cal}$ & $\operatorname{Exp}^{[2]}$ & $\mathrm{cal}$ & $\operatorname{Exp}^{[5]}$ \\
\hline$r(\AA)$ & 1.212 & 1.193 & 1.172 & 1.150 \\
$\theta(\mathrm{deg})$ & 133.8 & 134.1 & & \\
$v_{a}\left(\mathrm{~cm}^{-1}\right)$ & 1686 & 1618 & 1917 & 1904 \\
$v_{s}\left(\mathrm{~cm}^{-1}\right)$ & 1348 & 1318 & & \\
$v_{b}\left(\mathrm{~cm}^{-1}\right)$ & 733 & 750 & & \\
\hline
\end{tabular}
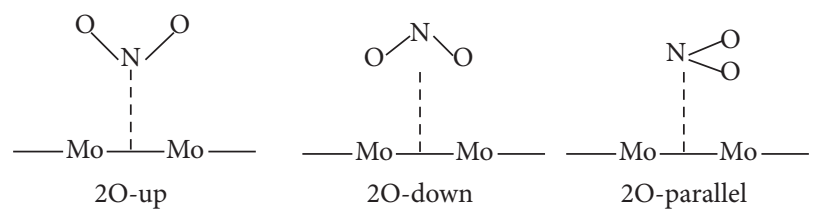

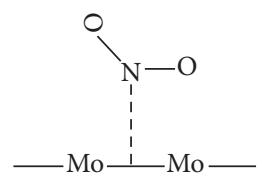

O-up-paralle

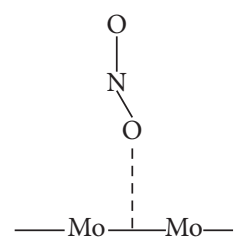

O-up-down
FIgURE 2: Schematic diagram of possible adsorption states of adsorbed $\mathrm{NO}_{2}$ molecules.

Let us study the adsorption of $\mathrm{O}$ atoms on the Mo (110) surface. It can be seen from Figure 4 and Table 3 that $\mathrm{MoO}\left(\mathbf{H}, \mu^{1}-\mathrm{O}\right)$ is the most stable structure. The adsorption energies of the four adsorption structures $\mathrm{MoO}$ $\left(\mathbf{H}, \mu^{1}-\mathrm{O}\right), \operatorname{MoO}\left(\mathbf{L}, \mu^{1}-\mathrm{O}\right), \operatorname{MoO}\left(\mathbf{S}, \mu^{1}-\mathrm{O}\right)$, and $\mathrm{MoO}(\mathbf{T}$, $\left.\eta^{1}-\mathrm{O}\right)$ are calculated to be $-7.71 \mathrm{eV},-7.57 \mathrm{eV},-7.02 \mathrm{eV}$, and $-6.32 \mathrm{eV}$, respectively. These data show that the adsorptions are strong. The adsorption of $\mathrm{N}$ and $\mathrm{O}$ atoms on the Mo (110) surface behaves similar to the adsorption of $\mathrm{N}$ and $\mathrm{O}$ atoms on the $\mathrm{W}$ (111) surface and the Fe (111) surface $[1,2]$. 

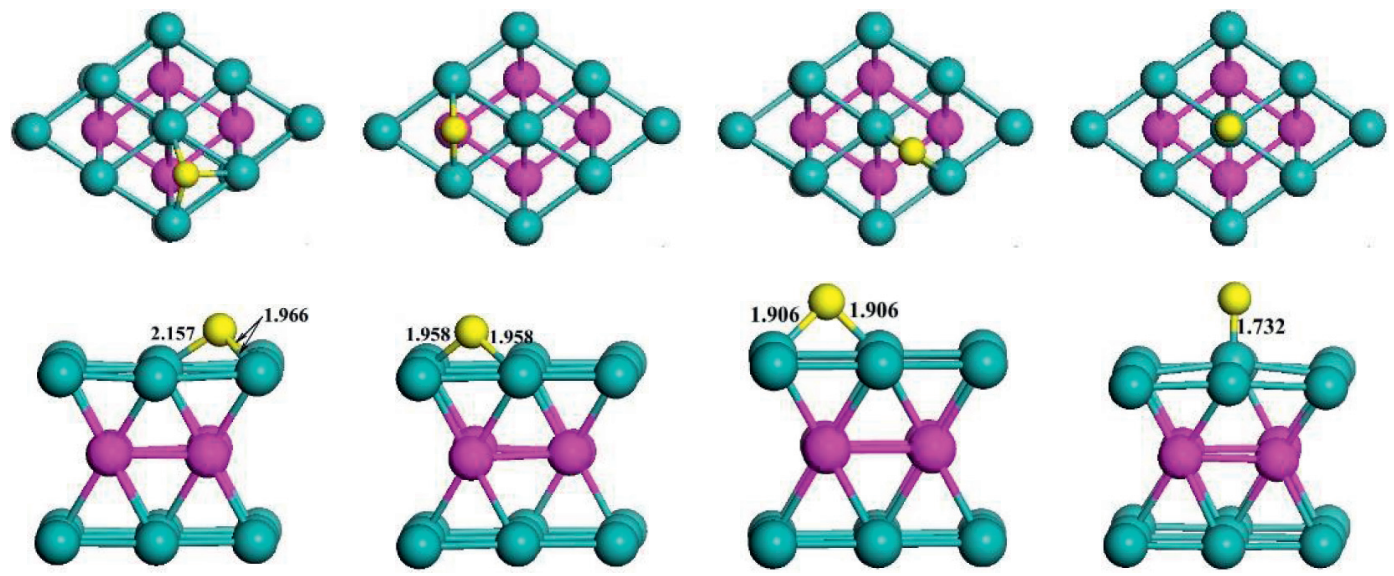

$$
\begin{aligned}
& \mathrm{E}_{\mathrm{ads}}=-7.02 \mathrm{eV} \\
& \mathrm{MoN}\left(\mathrm{H}, \mu^{1}-\mathrm{N}\right)
\end{aligned}
$$

$$
\begin{aligned}
& \mathrm{E}_{\mathrm{ads}}=-6.98 \mathrm{eV} \\
& \mathrm{MoN}\left(\mathrm{L}, \mu^{1}-\mathrm{N}\right)
\end{aligned}
$$

$$
\begin{aligned}
& \mathrm{E}_{\mathrm{ads}}=-6.16 \mathrm{eV} \\
& \operatorname{MoN}\left(\mathrm{S}, \mu^{1}-\mathrm{N}\right)
\end{aligned}
$$

$$
\mathrm{E}_{\mathrm{ads}}=-4.68 \mathrm{eV}
$$$$
\operatorname{MoN}\left(\mathrm{T}, \eta^{1}-\mathrm{N}\right)
$$

Figure 3: Adsorption structures of $\mathrm{N}$ atom on Mo (110) surface (the upper and lower layers are a top view and side view, respectively, the same below).

TABLE 2: Structural parameters of $\mathrm{N}$ atoms adsorption on Mo (110) surface.

\begin{tabular}{lcccccc}
\hline Site & $E_{\text {ads }}(\mathrm{eV})$ & $d_{\mathrm{N}-\mathrm{Mo}}(\AA)$ & $h(\AA)$ & $\Delta d_{12} / d_{0}(\%)$ & $\Delta d_{23} / d_{0}(\%)$ & $z_{1}(\AA)$ \\
\hline MoN $\left(\mathbf{H}, \mu^{1}-\mathrm{N}\right)$ & -7.02 & 1.966 & 1.250 & -1.8 & 1.1 & 0.121 \\
MoN $\left(\mathbf{L}, \mu^{1}-\mathrm{N}\right)$ & -6.98 & 1.949 & 1.251 & -2.1 & 1.2 & 0.038 \\
MoN $\left(\mathbf{S}, \mu^{1}-\mathrm{N}\right)$ & -6.16 & 1.906 & 1.376 & -2.1 & 1.1 & 0.103 \\
MoN $\left(\mathbf{T}, \eta^{1}-\mathrm{N}\right)$ & -4.68 & 1.732 & 1.704 & -2.2 & 0.87 & 0.152 \\
\hline
\end{tabular}

$h$ is the average binding height with respect to the first Mo layer; $\Delta d_{i j}$ is the average interlayer spacing relaxations between the $i$ and the $j$ layer; $Z_{1}$ and $Z_{2}$ represent the buckling in the first and second layer, respectively. The same definition is used in all subsequent tables.
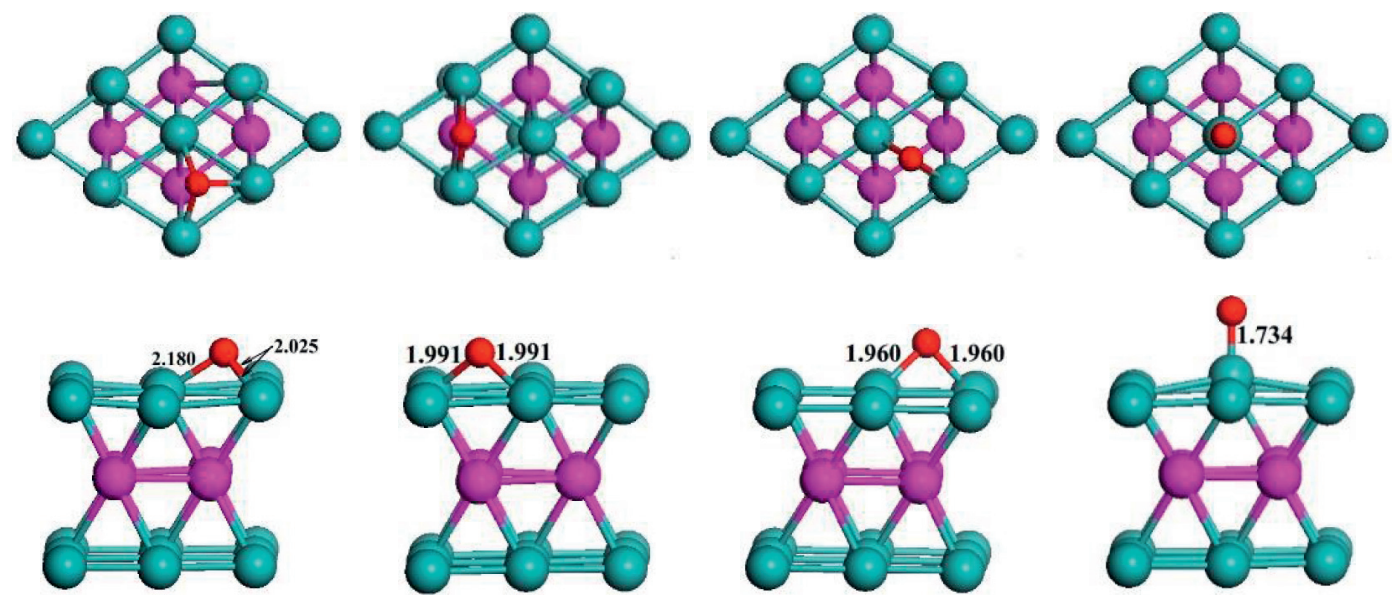

$\mathrm{E}_{\mathrm{ads}}=-7.71 \mathrm{eV}$
$\mathrm{MoO}\left(\mathrm{H}, \mu^{1}-\mathrm{O}\right)$

\begin{tabular}{|c|c|c|c|c|c|c|c|}
\hline Site & $E_{\mathrm{ads}}(\mathrm{eV})$ & $d_{\mathrm{O}-\mathrm{Mo}}(\AA)$ & $h(\AA)$ & $\Delta d_{12} / d_{0}(\%)$ & $\Delta d_{23} / d_{0}(\%)$ & $z_{1}(\AA)$ & $z_{2}(\AA)$ \\
\hline $\mathrm{MoO}\left(\mathbf{H}, \mu^{1}-\mathrm{O}\right)$ & -7.71 & 2.025 & 1.189 & -1.8 & 0.67 & 0.164 & 0.099 \\
\hline $\operatorname{MoO}\left(\mathbf{L}, \mu^{1}-\mathrm{O}\right)$ & -7.57 & 1.991 & 1.200 & -1.8 & 0.71 & 0.085 & 0.109 \\
\hline $\operatorname{MoO}\left(S, \mu^{1}-\mathrm{O}\right)$ & -7.02 & 1.960 & 1.464 & -2.7 & 0.73 & 0.178 & 0.006 \\
\hline $\operatorname{MoO}\left(\mathbf{T}, \eta^{1}-\mathrm{O}\right)$ & -6.32 & 1.734 & 2.100 & -1.4 & 0.51 & 0.547 & 0.057 \\
\hline
\end{tabular}

$$
\begin{aligned}
& \mathrm{E}_{\mathrm{ads}}=-7.57 \mathrm{eV} \\
& \mathrm{MoO}\left(\mathrm{L}, \mu^{1}-\mathrm{O}\right)
\end{aligned}
$$

$$
\begin{aligned}
& \mathrm{E}_{\mathrm{ads}}=-7.02 \mathrm{eV} \\
& \mathrm{MoO}\left(\mathrm{S}, \mu^{1}-\mathrm{O}\right)
\end{aligned}
$$$$
\mathrm{E}_{\mathrm{ads}}=-6.32 \mathrm{eV}
$$$$
\mathrm{MoO}\left(\mathrm{T}, \eta^{1}-\mathrm{O}\right)
$$

FIgURE 4: Adsorption structures of $\mathrm{O}$ atoms on the Mo (110) surface.

TABLE 3: Structural parameters $\mathrm{O}$ atom adsorption on the Mo (110) surface. 

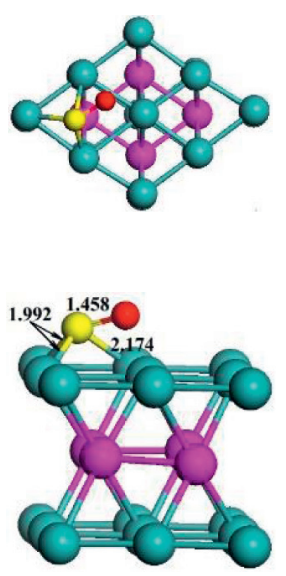

$\mathrm{E}_{\mathrm{ads}}=-3.75 \mathrm{eV}$ MoNO $\left(\mathrm{H}, \mu^{1}-\mathrm{N}\right)$
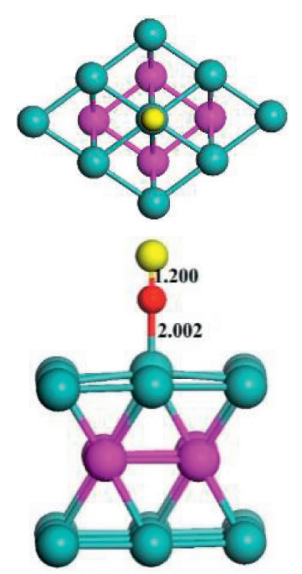

$\mathrm{E}_{\mathrm{ads}}=-0.92 \mathrm{eV}$ $\mathrm{MoNO}\left(\mathrm{T}, \eta^{1}-\mathrm{O}\right)$
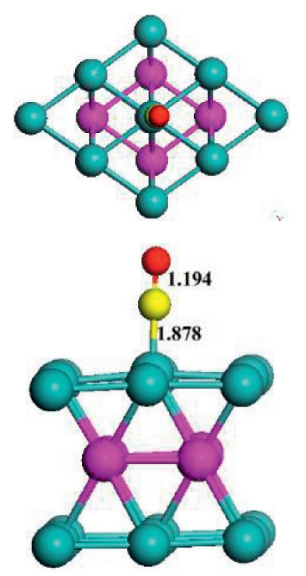

$\mathrm{E}_{\mathrm{ads}}=-2.78 \mathrm{eV}$ $\operatorname{MoNO}\left(\mathrm{T}, \eta^{1}-\mathrm{N}\right)$
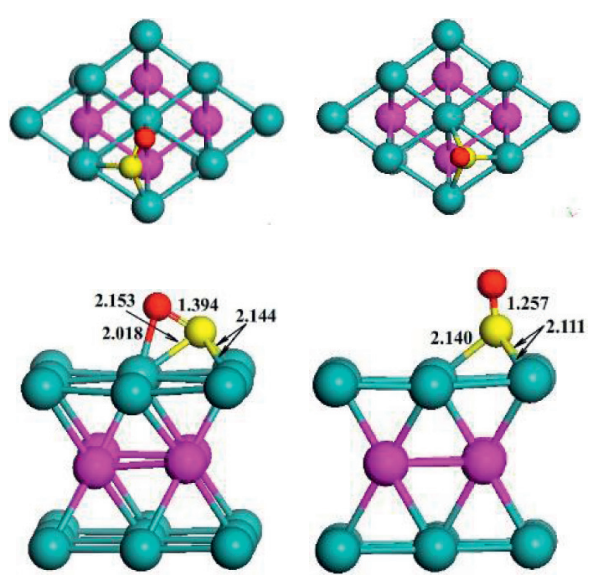

$\mathrm{E}_{\mathrm{ads}}=-3.57 \mathrm{eV}$ $\operatorname{MoNO}\left(\mathrm{H}, \mu^{2}-\mathrm{N}, \mathrm{O}\right)$
$\mathrm{E}_{\mathrm{ads}}=-3.01 \mathrm{eV}$

$\operatorname{MoNO}\left(\mathrm{H}, \eta^{1}-\mathrm{N}\right)$

Figure 5: Adsorption structures of NO molecule on the Mo (110) surface.

TABLE 4: Structural parameters of NO adsorption on the Mo (110) surface.

\begin{tabular}{|c|c|c|c|c|c|c|c|c|c|}
\hline Site & $E_{\text {ads }}(\mathrm{eV})$ & $\mathrm{d}_{\mathrm{N}-\mathrm{O}}(\AA)$ & $\theta(\operatorname{deg})$ & $d_{\mathrm{N}-\mathrm{Mo}}(\AA)$ & $h(\AA)$ & $\Delta d_{12} / d_{0}(\%)$ & $\Delta d_{23} / d_{0}(\%)$ & $z_{1}(\AA)$ & $z_{2}(\AA)$ \\
\hline $\operatorname{MoNO}\left(\mathbf{H}, \mu^{1}-\mathrm{N}\right)$ & -3.75 & 1.457 & 15.3 & 1.992 & 1.226 & -1.5 & 1.1 & 0.036 & 0.128 \\
\hline $\operatorname{MoNO}\left(\mathbf{T}, \eta^{1}-\mathrm{O}\right)$ & -0.92 & 1.201 & 90.0 & 2.002 & 2.189 & -3.5 & 1.2 & 0.279 & 0.038 \\
\hline $\operatorname{MoNO}\left(\mathbf{T}, \eta^{1}-\mathrm{N}\right)$ & -2.78 & 1.194 & 90.0 & 1.878 & 2.040 & -2.9 & 1.1 & 0.270 & 0.051 \\
\hline $\operatorname{MoNO}\left(\mathbf{H}, \mu^{2}-\mathrm{N}, \mathrm{O}\right)$ & -3.57 & 1.394 & 32.7 & 2.008 & 1.260 & -0.59 & 0.63 & 0.237 & 0.136 \\
\hline $\operatorname{MoNO}\left(\mathbf{H}, \eta^{1}-\mathrm{N}\right)$ & -3.01 & 1.257 & 81.9 & 2.111 & 1.338 & -3.0 & 1.1 & 0.122 & 0.058 \\
\hline
\end{tabular}

$\theta$ is the include angel of NO-surf.

3.4. Adsorption of NO on Mo (110) Surface. In order to study the dissociation of $\mathrm{NO}_{2}$ on the Mo (110) surface, it is very important to explore the interaction between $\mathrm{NO}$ and Mo (110). Similar to the abovementioned studies, four adsorption positions on the surface of Mo (110) are still used for NO adsorption. It can be seen from Figure 5 and Table 4 that NO/Mo (110) mainly has the following five structures: $\operatorname{MoNO}\left(\mathbf{H}, \mu^{1}-\mathrm{N}\right)$, MoNO $\left(\mathbf{T}, \eta^{1}-\mathrm{O}\right)$, MoNO $\left(\mathbf{T}, \eta^{1}-\mathrm{N}\right)$, MoNO $\left(\mathbf{H}, \mu^{2}-\mathrm{N}, \mathrm{O}\right)$, and MoNO $\left(\mathbf{H}, \eta^{1}-\mathrm{N}\right)$, where MoNO $\left(\mathbf{H}, \mu^{1}-\mathrm{N}\right)$ is the most stable structure, and its adsorption energy is $-3.75 \mathrm{eV}$. The second and third stable structures are MoNO $\left(\mathrm{H}, \mu^{2}-\mathrm{N}, \mathrm{O}\right)$ and MoNO $\left(\mathrm{H}, \eta^{1}-\mathrm{N}\right)$ with corresponding adsorption energies of $-3.57 \mathrm{eV}$ and $-3.01 \mathrm{eV}$, respectively. From these structures, it is found that $\mathrm{NO}$ acts mainly through $\mathrm{N}$ atoms with Mo (110) surface.

3.5. Adsorption of $\mathrm{NO}_{2}$ on $\mathrm{Mo}$ (110) Surface. $\mathrm{NO}_{2}$ molecule has a curved structure, and the inner angle of $\mathrm{O}-\mathrm{N}-\mathrm{O}$ is $133.8^{\circ}$. Calculations show that $\mathrm{NO}_{2}$ takes effect mainly through $\mathrm{N}$ atoms on the Mo (110) surface, which is similar to the adsorption of NO. According to Figure 6 and Table 5, $\mathrm{NO}_{2} / \mathrm{Mo}$ (110) mainly has the following stable structures: $\mathrm{MoNO}_{2}\left(\mathbf{T}, \mu^{1}-\mathrm{N}\right), \mathrm{MoNO}_{2}\left(\mathbf{H}, \mu^{3}-\mathrm{N}, \mathrm{O}, \mathrm{O}^{\prime}\right), \mathrm{MoNO}_{2}\left(\mathbf{S}, \eta^{2}-\right.$ $\left.\mathrm{O}, \mathrm{O}^{\prime}\right), \mathrm{MoNO}_{2}\left(\mathbf{L}, \eta^{2}-\mathrm{O}, \mathrm{O}^{\prime}\right), \mathrm{MoNO}_{2}\left(\mathrm{~T}, \eta^{1}-\mathrm{O}\right), \mathrm{MoNO}_{2}(\mathrm{~T}$, $\left.\eta^{2}-\mathrm{O}, \mathrm{O}^{\prime}\right), \mathrm{MoNO}_{2}\left(\mathbf{L}, \eta^{1}-\mathrm{N}\right)$, and $\mathrm{MoNO}_{2}\left(\mathbf{S}, \eta^{1}-\mathrm{N}\right)$. As can be seen from Figure $6, \mathrm{MoNO}_{2}\left(\mathrm{~T}, \mu^{1}-\mathrm{N}\right)$ and $\mathrm{MoNO}_{2}(\mathrm{H}$, $\left.\mu^{3}-\mathrm{N}, \mathrm{O}, \mathrm{O}^{\prime}\right)$ are the most and second stable structures, and the adsorption energies are $-3.83 \mathrm{eV}$ and $-3.40 \mathrm{eV}$, respectively. In both structures, $\mathrm{NO}_{2}$ is obliquely adsorbed on the surface. $\mathrm{MoNO}_{2}\left(\mathrm{~S}, \eta^{2}-\mathrm{O}, \mathrm{O}^{\prime}\right)$, and $\mathrm{MoNO}_{2}\left(\mathrm{~L}, \eta^{2}-\mathrm{O}\right.$, $\left.\mathrm{O}^{\prime}\right)$ are also two stable structures with corresponding adsorption energies of $-2.81 \mathrm{eV}$ and $-2.60 \mathrm{eV}$, respectively.

3.6. Deoxidation Process of $\mathrm{NO}_{2}$ on Mo (110) Surface. Next, we will focus on the deoxidation process of $\mathrm{NO}_{2}$ on Mo (110) surface. Generally, the interaction between $\mathrm{NO}_{2}$ and Mo (110) surface is carried out according to the following steps:

$$
\begin{aligned}
& \text { Step 1: } \mathrm{NO}_{2(\text { gas })} \longrightarrow \mathrm{NO}_{2}(\text { ads }) \\
& \text { Step 2: } \mathrm{NO}_{2}(\text { ads }) \longrightarrow \mathrm{NO}_{(\mathrm{ads})}+\mathrm{O}_{(\mathrm{ads})} \\
& \text { Step 3: } \mathrm{NO}_{(\mathrm{ads})}+\mathrm{O}_{(\mathrm{ads})} \longrightarrow \mathrm{N}_{(\mathrm{ads})}+2 \mathrm{O}_{(\mathrm{ads})}
\end{aligned}
$$

The climbing configuration elastic band method is used to study the decomposition process of $\mathrm{NO}_{2}$ on Mo (110) surface. The CI-NEB method requires determining the initial and final states of the reaction. So in the deoxidation process of the first part (Step 2), the most stable structure of $\mathrm{NO}_{2} / \mathrm{Mo}$ (110) is selected as the initial state, that is, $\mathrm{MoNO}_{2}\left(\mathrm{~T}, \mu^{1}-\mathrm{N}\right)$, $\mathrm{MoNO}_{2}\left(\mathbf{H}, \mu^{3}-\mathrm{N}, \mathrm{O}, \mathrm{O}^{\prime}\right)$, and $\mathrm{MoNO}_{2}\left(\mathbf{S}, \eta^{2}-\mathrm{O}, \mathrm{O}^{\prime}\right)$ as the initial state of the first step deoxidation process, and the three structures are named LM1-1, LM1-2, LM1-3, respectively. In order to determine the structure of the final state $\mathrm{NO}_{(\mathrm{ads})}+\mathrm{O}_{(\mathrm{ads})}$, it can be seen from the adsorption of $\mathrm{NO}$ and $\mathrm{O}$ on Mo (110) surface that they are the most stable structures at the hollow position. Therefore, NO was placed 

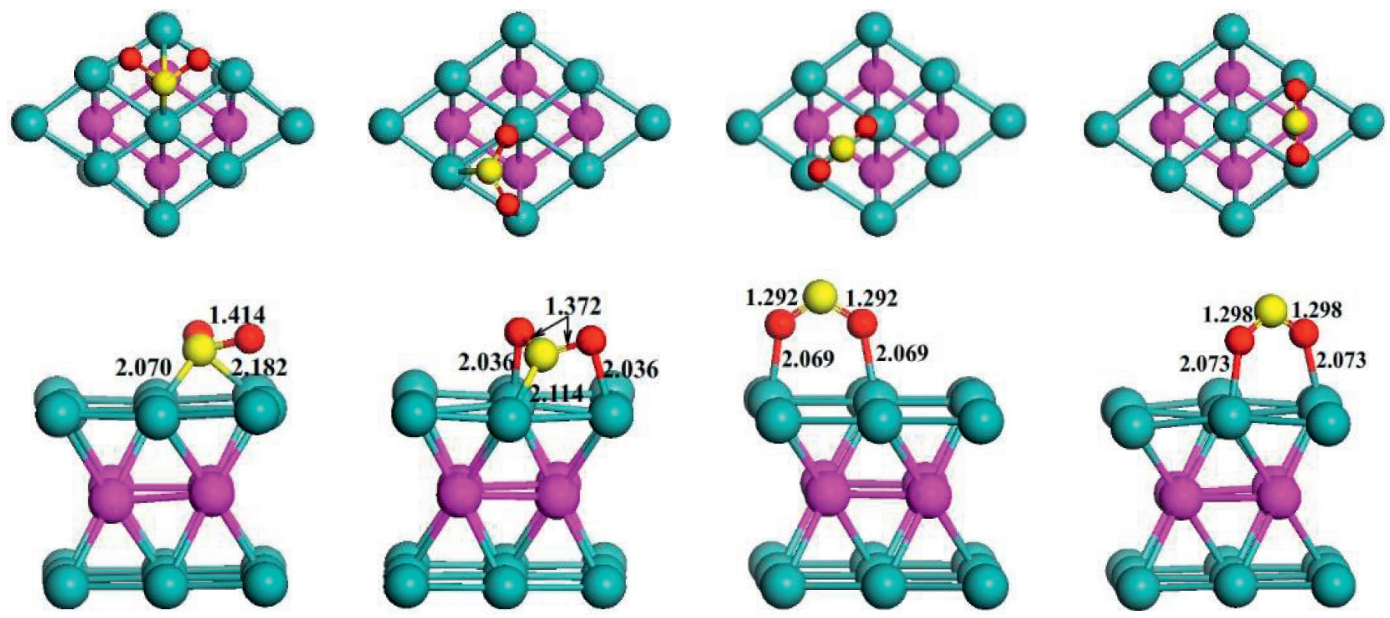

$\mathrm{E}_{\mathrm{ads}}=-3.83 \mathrm{eV}$

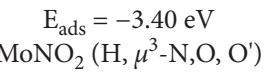

$\mathrm{E}_{\mathrm{ads}}=-2.81 \mathrm{eV}$

$\mathrm{MoNO}_{2}\left(\mathrm{~S}, \eta^{2}-\mathrm{O}, \mathrm{O}^{\prime}\right)$

$\mathrm{E}_{\mathrm{ads}}=-2.60 \mathrm{eV}$ $\mathrm{MoNO}_{2}\left(\mathrm{~L}, \eta^{2}-\mathrm{O}, \mathrm{O}^{\prime}\right)$
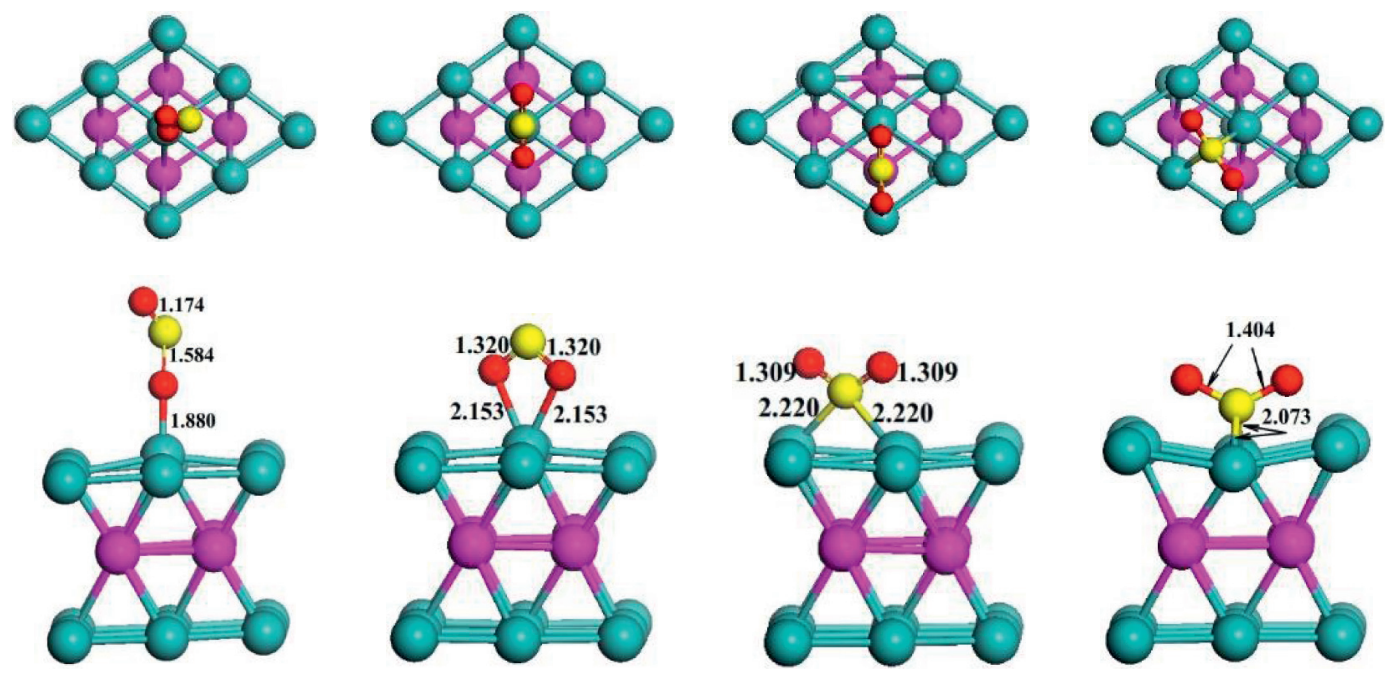

$\mathrm{E}_{\mathrm{ads}}=-1.74 \mathrm{eV}$

$\mathrm{E}_{\mathrm{ads}}=-2.37 \mathrm{eV}$

$\mathrm{MoNO}_{2}\left(\mathrm{~T}, \eta^{2}-\mathrm{O}, \mathrm{O}^{\prime}\right)$

$$
\begin{gathered}
\mathrm{E}_{\mathrm{ads}}=-2.06 \mathrm{eV} \\
\mathrm{MoNO}_{2}\left(\mathrm{~L}, \eta^{1}-\mathrm{N}\right)
\end{gathered}
$$

$\mathrm{E}_{\mathrm{ads}}=-2.23 \mathrm{eV}$

$\mathrm{MoNO}_{2}\left(\mathrm{~S}, \eta^{1}-\mathrm{N}\right)$

Figure 6: Adsorption structure of $\mathrm{NO}_{2}$ molecule on the Mo (110) surface.

\begin{tabular}{|c|c|c|c|c|c|c|c|c|c|c|}
\hline Site & $E_{\text {ads }}(\mathrm{eV})$ & $d_{\mathrm{N}-\mathrm{O}}(\AA)$ & $\varphi(\mathrm{deg})$ & $\theta(\mathrm{deg})$ & $d(\AA)$ & $h(\AA)$ & $\Delta d_{12} / d_{0}(\%)$ & $\Delta d_{23} / d_{0}(\%)$ & $z_{1}(\AA)$ & $z_{2}(\AA)$ \\
\hline $\mathrm{MoNO}_{2}\left(\mathbf{T}, \mu^{1}-\mathrm{N}\right)$ & -3.83 & 1.141 & 107.5 & 33.6 & 2.181 & 1.441 & -0.62 & 1.02 & 0.120 & 0.014 \\
\hline $\mathrm{MoNO}_{2}\left(\mathbf{H}, \mu^{3}-\mathrm{N}, \mathrm{O}, \mathrm{O}^{\prime}\right)$ & -3.40 & 1.372 & 113.8 & 41.3 & 2.113 & 1.587 & -1.06 & 0.56 & 0.235 & 0.088 \\
\hline $\mathrm{MoNO}_{2}\left(\mathrm{~S}, \eta^{2}-\mathrm{O}, \mathrm{O}^{\prime}\right)$ & -2.81 & 1.292 & 111.2 & 89.8 & 2.069 & 2.134 & 0.81 & 1.09 & 0.208 & 0.040 \\
\hline $\mathrm{MoNO}_{2}\left(\mathbf{L}, \eta^{2}-\mathrm{O}, \mathrm{O}^{\prime}\right)$ & -2.60 & 1.298 & 114.4 & 90.0 & 3.129 & 2.127 & -1.95 & 0.37 & 0.207 & 0.106 \\
\hline $\mathrm{MoNO}_{2}\left(\mathbf{T}, \eta^{1}-\mathrm{O}\right)$ & -1.74 & 1.173 & 111.6 & 90.0 & 1.875 & 2.177 & -1.19 & 1.04 & 0.436 & 0.059 \\
\hline $\mathrm{MoNO}_{2}\left(\mathrm{~T}, \eta^{2}-\mathrm{O}, \mathrm{O}^{\prime}\right)$ & -2.37 & 1.320 & 106.2 & 90.0 & 2.670 & 1.998 & -3.6 & 1.10 & 0.216 & 0.031 \\
\hline $\mathrm{MoNO}_{2}\left(\mathbf{L}, \eta^{1}-\mathrm{N}\right)$ & -2.06 & 1.310 & 120.3 & 90.0 & 2.220 & 1.612 & -2.02 & 0.99 & 0.202 & 0.099 \\
\hline $\mathrm{MoNO}_{2}\left(\mathrm{~S}, \eta^{1}-\mathrm{N}\right)$ & -2.23 & 1.404 & 124.6 & 90.0 & 2.073 & 1.255 & 0.025 & 0.97 & 0.171 & 0.042 \\
\hline
\end{tabular}

TABLE 5: Structural parameters of $\mathrm{NO}_{2}$ adsorption on the Mo (110) surface.

$\varphi$ is the included angle of $\mathrm{O}_{1}-\mathrm{N}-\mathrm{O}_{2}, \theta$ is the inner angle of $\mathrm{NO}_{2}$-surf.

at the hollow position, and $\mathrm{O}$ was placed at the supercell $p$ $(2 \times 2)$. After calculations, it is found that only one structure of LM2-1 is stable (the specific structure as shown in
Figure 7). Figure 7 shows the possible potential energy surface (PES) of the first step deoxidation process constructed. 


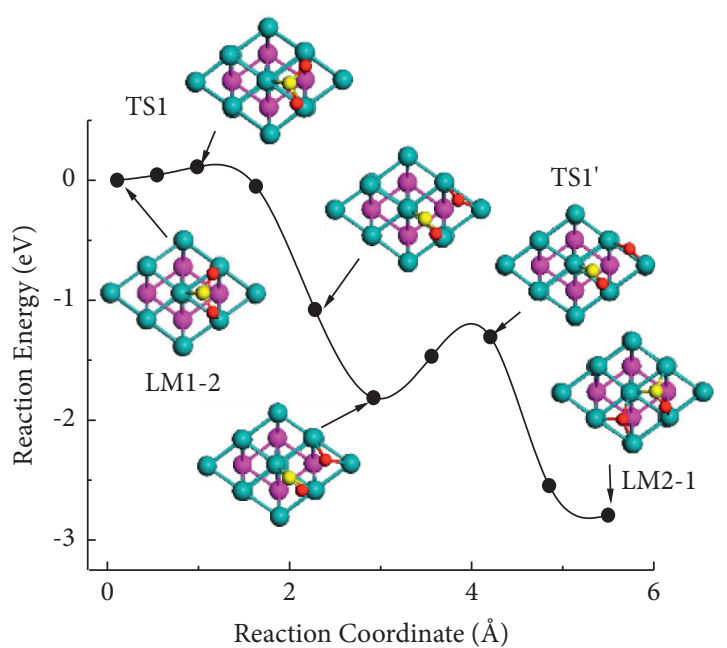

(a)

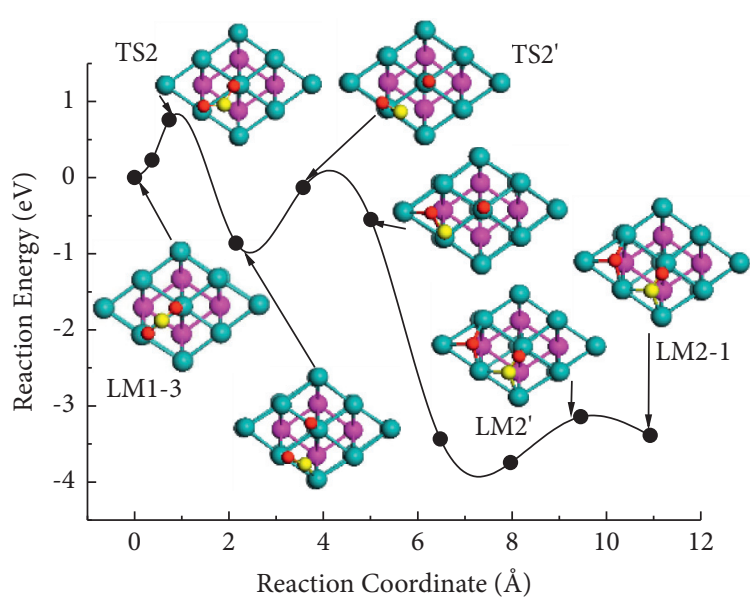

(b)

Figure 7: Potential energy surface of $\mathrm{NO}_{2}$ molecule in the first step deoxidation process of Mo (110).

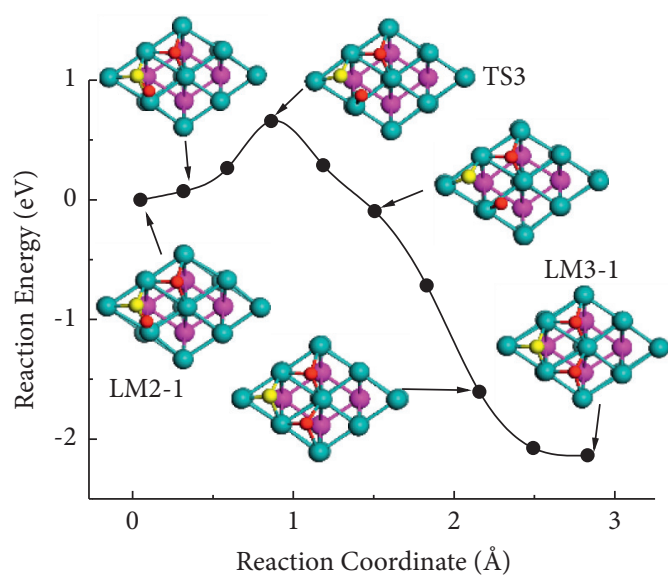

(a)

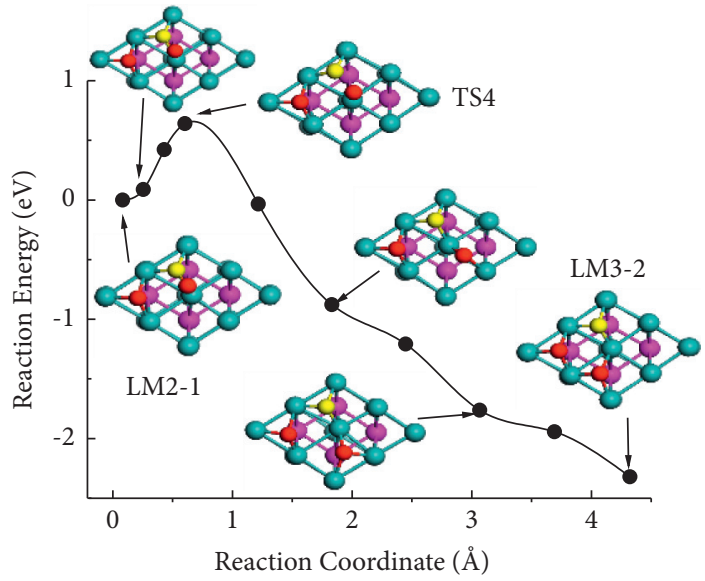

(b)

FIgURE 8: Potential energy surface of $\mathrm{NO}_{2}$ molecule in the second step deoxidation process of Mo (110).

Path 1: As shown in Figure 7(a), the most possible pathway of the first deoxidation process of $\mathrm{NO}_{2}$ on $\mathrm{Mo}$ (110) surface starts from LM1-2 to LM2-1 via the transition states TS1 and TS1'. The heat release in the whole process is up to $2.79 \mathrm{eV}$. During this process, it needs to cross two transition states with energy barriers of $0.11 \mathrm{eV}$ and $0.50 \mathrm{eV}$, respectively. The activated $\mathrm{N}-\mathrm{O}$ bond length changes from $1.372 \AA$ in the initial state to $1.419 \AA$ in TS1, then extend to $2.709 \AA$ in $\mathrm{TS}^{\prime}{ }^{\prime}$ and finally to be $2.741 \AA$ in final state LM2-1. The bond angle of $\mathrm{O}-\mathrm{N}-\mathrm{O}$ changes from $113.7^{\circ}$ in the initial state to $110.39^{\circ}$ in TS1. The activated oxygen atom gradually crosses the short bridge position and finally reaches the hollow position.

Path 2: Another possible pathway of the first deoxidation process is explored from LM1-3 to LM2-1. The heat release in the whole process reaches $3.38 \mathrm{eV}$. It needs to cross the transition states TS2 and TS2'. The potential barriers are $0.76 \mathrm{eV}$ and $0.73 \mathrm{eV}$, respectively. The activated $\mathrm{N}-\mathrm{O}$ bond length changes from $1.372 \AA$ in the initial state to $1.419 \AA$ in TS2, then extend to $2.709 \AA$ in TS2 ${ }^{\prime}$ and finally to be $2.741 \AA$ in final state LM2-1. The bond angle of $\mathrm{O}-\mathrm{N}-\mathrm{O}$ changes from $113.2^{\circ}$ in the initial state to $113.1^{\circ}$ in TS2. The activated oxygen atom gradually moves from the top position to the hollow position.

For the second deoxidation process (Step 3), the initial state is the final state of the previous step, namely, LM2-1 and LM2-2. For the determination of the final state, it is also necessary to determine the coadsorption of $\mathrm{N}$ and $2 \mathrm{O}$. After calculation, it is found that there are two stable structures, namely, LM3-1 and LM3-2 (as seen in Figure 8).

Path 3: Figure 8(a) is the potential energy surface of the second constructed deoxidation process in step 3. It can be seen from the figure that the process needs to experience the transition state of TS3 from LM2-1 to LM3-1. The heat release in the whole process is $2.13 \mathrm{eV}$ and the height across the potential barrier is $0.66 \mathrm{eV}$. In 
this path, the $\mathrm{N}-\mathrm{O}$ bond is broken and the atoms of oxygen and nitrogen are adsorbed at the hollow sites, respectively.

Path 4: For the second deoxidation process of $\mathrm{NO}_{2}$ on Mo (110) surface, $\quad \mathrm{NO}(\mathrm{ads})+\mathrm{O}(\mathrm{ads}) \longrightarrow$ $\mathrm{N}$ (ads) + 2O(ads), another possible path from LM2-1 via the transition state of TS4 into LM3-2 is exothermic by $2.32 \mathrm{eV}$ with the calculated barrier of $0.64 \mathrm{eV}$, as shown in Figure 8(b). In TS4, the N-O bond is elongated to be $1.83 \AA$. After the TS4, the dissociating oxygen crosses the top site, short bridge site, and finally adsorbs at the hollow site.

In summary, the preferable reaction pathway of $\mathrm{NO}_{2}$ (gas) + slab $\longrightarrow$ LM1-2 $\longrightarrow$ TS1 $\longrightarrow$ LM2-

$1 \longrightarrow \mathrm{TS} 4 \longrightarrow \mathrm{LM} 3-2$ is calculated to be exothermic by $5.11 \mathrm{eV}$, with the first, second deoxidation activation barriers of $0.11 \mathrm{eV}, 0.64 \mathrm{eV}$, respectively. These results have shown that $\mathrm{NO}_{2}$ molecule can dissociate completely on the perfect Mo (110) surface, which is in agreement with the experiment $[33,34]$. It also indicates that Mo $\left(\begin{array}{lll}1 & 1 & 0\end{array}\right)$ surface exhibits good catalytic activity to decompose $\mathrm{NO} x$ as well as other gas, such as $\mathrm{H}_{2} \mathrm{~S}[54,55]$.

\section{Conclusions}

Based on the density functional theory, the adsorption and decomposition of $\mathrm{NO}_{x}(x=1,2)$ on the Mo $(110)$ surface were calculated by the first principle. The results show that the stable structures of $\mathrm{NO}_{2} / \mathrm{Mo}(110)$ coordination are $\mathrm{MoNO}_{2}\left(\mathrm{~T}, \mu^{1}-\mathrm{N}\right)$, $\mathrm{MoNO}_{2}\left(\mathbf{H}, \mu^{3}-\mathrm{N}, \mathrm{O}, \mathrm{O}^{\prime}\right), \mathrm{MoNO}_{2}\left(\mathbf{S}, \eta^{2}-\mathrm{O}, \mathrm{O}^{\prime}\right)$, and $\mathrm{MoNO}_{2}$ $\left(\mathrm{L}, \eta^{2}-\mathrm{O}, \mathrm{O}^{\prime}\right)$. The corresponding adsorption energies are $-3.83 \mathrm{eV},-3.40 \mathrm{eV},-2.81 \mathrm{eV}$, and $-2.60 \mathrm{eV}$, respectively. The stable structure of NO/Mo (110) are $\operatorname{MoNO}\left(\mathbf{H}, \mu^{1}-\mathrm{N}\right)$, MoNO $\left(\mathbf{H}, \mu^{2}-\mathrm{N}, \mathrm{O}\right)$, and $\mathrm{MoNO}\left(\mathbf{H}, \eta^{1}-\mathrm{N}\right)$ and the corresponding adsorption energies are $-3.75 \mathrm{eV},-3.57 \mathrm{eV}$, and $-3.01 \mathrm{eV}$, respectively. $\mathrm{N}$ and $\mathrm{O}$ are easily adsorbed at the hollow site of the Mo (110) surface, and their adsorption energies are $-7.02 \mathrm{eV}$ and $-7.70 \mathrm{eV}$. The study on the preferable decomposition process of $\mathrm{NO}_{x}(x=1,2)$ on Mo (110) shows that the potential barriers of the first and second deoxidation processes of $\mathrm{MoNO}_{2}\left(\mathrm{H}, \mu^{3}-\mathrm{N}\right.$, $\left.\mathrm{O}, \mathrm{O}^{\prime}\right)$ are $0.11 \mathrm{eV}$ and $0.64 \mathrm{eV}$, respectively. All these findings indicate that the Mo (110) surface exhibits good catalytic activity to decompose $\mathrm{NO} x$.

\section{Data Availability}

The raw/processed data required to reproduce these findings cannot be shared at this time as the data also forms part of an ongoing study.

\section{Conflicts of Interest}

The authors declare that they have no conflicts of interest.

\section{Acknowledgments}

This work was supported financially by the National Natural Science Foundation of China (Grant nos. 61620106006 and 61871292), and the scientific research project of Zhejiang
Provincial Department of Education in 2020 (Grant No: Y202044305)

\section{References}

[1] D. G. Musaev, H. T. Chen, and H. L. Chen, "Density functional studies of the adsorption and dissociation of $\mathrm{NO}(x)(x=$ $1,2)$ molecules on the W(111) surface," Journal of Physics Chemical C, vol. 113, pp. 5300-5306, 2009.

[2] H.-L. Chen, S.-Y. Wu, H.-T. Chen et al., "Theoretical study on adsorption and dissociation of $\mathrm{NO}_{2}$ molecule on $\mathrm{Fe}(111)$ surface," Langmuir, vol. 26, no. 10, pp. 7157-7164, 2010.

[3] X. R. Shi, J. G. Wang, and K. Hermann, "CO and NO adsorption and dissociation at the $\mathrm{B}-\mathrm{Mo}(2) \mathrm{C}(0001)$ surface: a density functional theory study," Journal of Physics Chemical C, vol. 114, pp. 13630-13670, 2010.

[4] M. K. Zhang, M. Xia, D. C. Li, Z. Sun, Y. You, and J. Dou, "The effects of transitional metal element doping on the $\mathrm{Cs}(\mathrm{I})$ adsorption of kaolinite (001): a density functional theory study," Applied Surface Science, vol. 547, Article ID 149210, 2021.

[5] CA. Casey-Stevens, H. Smundsson, E. Skúlason, and AL. Garden, "A density functional theory study of the mechanism and onset potentials for the major products of NO electroreduction on transition metal catalysts," Applied Surface Science, vol. 552, Article ID 149063, 2021.

[6] B. Wang, M. X. Wang, L. N. Han et al., "Improved activity and $\mathrm{SO}_{2}$ resistance by $\mathrm{Sm}$-modulated redox of $\mathrm{MnCeSmTiO}_{x}$ mesoporous amorphous oxides for low-temperature NH3SCR of NO," ACS Catalysis, vol. 10, no. 16, pp. 9034-9045, 2020.

[7] Y. Guo, Y. Zhang, W. Wu, Y. Liu, and Z. Zhou, "Transition metal (Pd, Pt, Ag, Au) decorated InN monolayer and their adsorption properties towards $\mathrm{NO}_{2}$ : density functional theory study," Applied Surface Science, vol. 455, pp. 106-114, 2018.

[8] Y. Liu, T. Shi, Q. L. Si, and T. Liu, "Adsorption and sensing performances of transition metal ( $\mathrm{Pd}, \mathrm{Pt}, \mathrm{Ag}$ and $\mathrm{Au})$ doped $\mathrm{MoTe}_{2}$ monolayer upon $\mathrm{NO}_{2}$ : a DFT study," Physics Letters A, vol. 391, Article ID 127117, 2021.

[9] Z. Xiao, W. Wu, X. W. Wu, and Z. Youfa, "Adsorption of $\mathrm{NO}_{2}$ on monolayer $\mathrm{MoS}_{2}$ doped with $\mathrm{Fe}, \mathrm{Co}$, and $\mathrm{Ni}, \mathrm{Cu}$ : a computational investigation," Chemical Physics Letters, vol. 755, Article ID 137768, 2020.

[10] J. Wang, Z. Peng, Y. Chen, W. Bao, L. Chang, and G. Feng, "In-situ hydrothermal synthesis of Cu-SSZ-13/cordierite for the catalytic removal of $\mathrm{NO}_{x}$ from diesel vehicles by NH3," Chemical Engineering Journal, vol. 263, pp. 9-19, 2015.

[11] J. C. Wang, Z. L. Peng, H. Qiao et al., "Influence of aging on in situ hydrothermally synthesized Cu-SSZ-13 catalyst for $\mathrm{NH}_{3}$ SCR reaction," RSC Advances, vol. 4, Article ID 42403, 2014.

[12] A. Hrabar, J. Hein, O. Y. Gutiérrez, and J. A. Lercher, "Selective poisoning of the direct denitrogenation route in o-propylaniline $\mathrm{HDN}$ by DBT on $\mathrm{Mo}$ and $\mathrm{NiMo} / \gamma-\mathrm{Al}_{2} \mathrm{O}_{3}$ sulfide catalysts," Journal of Catalysis, vol. 281, no. 2, pp. 325-338, 2011.

[13] W. Chen, H. Nie, D. Li, X. Long, J. van Gestel, and F. Maugé, "Effect of $\mathrm{Mg}$ addition on the structure and performance of sulfide $\mathrm{Mo} / \mathrm{Al}_{2} \mathrm{O}_{3}$ in $\mathrm{HDS}$ and $\mathrm{HDN}$ reaction," Journal of Catalysis, vol. 344, pp. 420-433, 2016.

[14] B. Behnejad, M. Abdouss, and A. Tavasoli, "Comparison of performance of $\mathrm{Ni}-\mathrm{Mo} / \gamma$-alumina catalyst in HDS and HDN reactions of main distillate fractions," Petroleum Science, vol. 16, no. 3, pp. 645-656, 2019.

[15] X. Zhang, F. F. Jia, and S. X. Song, "Recent advances in structural engineering of molybdenum disulfide for 
electrocatalytic hydrogen evolution reaction," Chemical Engineering Journal, vol. 405, Article ID 127013, 2021.

[16] Y. H. Chang, C. T. Lin, T. Y. Chen et al., "Highly efficient electrocatalytic hydrogen production by MoSxGrown on graphene-protected 3D Ni foams," Advanced Materials, vol. 25, no. 5, pp. 756-760, 2013.

[17] Y. Gu, A. P. Wu, Y. Q. Jiao et al., "Two-dimensional porous molybdenum phosphide/nitride heterojunction nanosheets for $\mathrm{pH}$-universal hydrogen evolution reaction," Angewandte Chemie International Edition, vol. 60, no. 12, pp. 6673-6681, 2021.

[18] T. Li, M. Virginie, and A. Y. Khodakov, "Effect of potassium promotion on the structure and performance of alumina supported carburized molybdenum catalysts for FischerTropsch synthesis," Applied Catalysis A: General, vol. 542, pp. 154-162, 2017.

[19] A. Alayat, E. Echeverria, D. N. Mcllroy, and A. G. McDonald, "Enhancement of the catalytic performance of silica nanosprings (NS)-supported iron catalyst with copper, molybdenum, cobalt and ruthenium promoters for Fischer-Tropsch synthesis," Fuel Processing Technology, vol. 177, pp. 89-100, 2018.

[20] A. J. Majewski, S. K. Singh, N. K. Labhasetwar, and R. Steinberger-Wilckens, "Nickel-molybdenum catalysts for combined solid oxide fuel cell internal steam and dry reforming," Chemical Engineering Science, vol. 232, Article ID 116341, 2021.

[21] D. A. Osinkin, S. M. Beresnev, and N. I. Lobachevskaya, "Symmetrical solid oxide fuel cell with strontium ferritemolybdenum electrodes," Russian Journal of Electrochemistry, vol. 53, no. 6, pp. 665-669, 2017.

[22] M. E. Bartram, R. G. Windham, and B. E. Koel, "Coadsorption of nitrogen dioxide and oxygen on platinum(111)," Langmuir, vol. 4, no. 2, pp. 240-246, 1988.

[23] M. E. Bartram, R. G. Windham, and B. E. Koel, "The molecular adsorption of nitrogen dioxide on $\mathrm{Pt}(111)$ studied by temperature programmed desorption and vibrational spectroscopy," Surface Science, vol. 184, no. 1-2, pp. 57-74, 1987.

[24] D. Dahlgren and J. C. Hemminger, "Decomposition of $\mathrm{NO}_{2}$ to NO and O on Pt(111)," Surface Science Letters, vol. 123, pp. 739-742, 1982.

[25] U. Schwalke, J. E. Parmeter, and W. H. Weinberg, "The adsorption of $\mathrm{NO}_{2}$ on clean $\mathrm{Ru}(001)$ and $\mathrm{Ru}(001)$ modified chemically by ordered overlayers of oxygen adatoms," Surface Science, vol. 178, no. 1-3, pp. 625-634, 1986.

[26] T. Jirsak, J. Dvorak, and J. A. Rodriguez, "Adsorption of $\mathrm{NO}_{2}$ on $\mathrm{Rh}(111)$ and $\mathrm{Pd} / \mathrm{Rh}(111)$ : photoemission studies," Surface Science, vol. 436, pp. 683-690, 1999.

[27] S. R. Bare, K. Griffiths, W. N. Lennard, and H. T. Tang, "Generation of atomic oxygen on $\mathrm{Ag}(111)$ and $\mathrm{Ag}(110)$ using $\mathrm{NO}_{2}$ : a TPD, LEED, HREELS, XPS and NRA study," Surface Science, vol. 342, no. 1-3, pp. 185-198, 1995.

[28] G. Polzonetti, P. Alnot, and C. R. Brundle, "The adsorption and reactions of $\mathrm{NO}_{2}$ on the $\mathrm{Ag}(111)$ surface," Surface Science, vol. 238, no. 1-3, pp. 226-236, 1990.

[29] W. A. Brown, P. Gardner, and D. A. King, "The adsorption of $\mathrm{NO}_{2}$ on Ag $\{111\}$ : a low temperature RAIRS study," Surface Science, vol. 330, no. 1, pp. 41-47, 1995.

[30] D. T. Wickham, B. A. Banse, and B. E. Koel, "Adsorption of nitrogen dioxide and nitric oxide on Pd(lll)," Surface Science, vol. 243, no. 1-3, pp. 83-95, 1991.

[31] M. E. Bartram and B. E. Koel, "The molecular adsorption of $\mathrm{NO}_{2}$ and the formation of $\mathrm{N}_{2} \mathrm{O}_{3}$ on $\mathrm{Au}(111)$," Surface Science, vol. 213, no. 1, pp. 137-156, 1989.
[32] J. Wang, M. R. Voss, H. Busse, and B. E. Koel, “Chemisorbed oxygen on $\mathrm{Au}(111)$ produced by a novel route: reaction in condensed films of $\mathrm{NO}_{2}+\mathrm{H}_{2} \mathrm{O}$," The Journal of Physical Chemistry B, vol. 102, no. 24, pp. 4693-4696, 1998.

[33] T. Jirsak, M. Kuhn, and J. A. Rodriguez, "Chemistry of $\mathrm{NO}_{2}$ on $\mathrm{Mo}(110)$ : decomposition reactions and formation of $\mathrm{MoO}_{2}$," Surface Science, vol. 457, no. 1-2, pp. 254-266, 2000.

[34] K. T. Queeney and C. M. Friend, "Dinitrosyl intermediate for $\mathrm{N} 2 \mathrm{O}$ formation from reaction of $\mathrm{NO}$ on $\mathrm{Mo}(110)$," The Journal of Chemical Physics, vol. 107, no. 16, pp. 6432-6442, 1997.

[35] K. Irokawa, R. Tanaka, and H. Miki, "Adsorption state of NO on $\mathrm{Mo}(100)$ surface studied by ESDIAD," Surface Science, vol. 602, no. 21, pp. 3438-3444, 2008.

[36] G. Kresse, J. Furthmüller, and J. ller, "Efficient iterative schemes for ab initio total-energy calculations using a planewave basis set," Physical Review. B, Condensed Matter, vol. 54, pp. 11169-11186, 1996.

[37] G. Kresse and J. Hafner, "Ab initio molecular-dynamics simulation of the liquid-metal-amorphous-semiconductor transition in germanium," Physical Review B, vol. 49, Article ID 14251, 1994.

[38] G. Kresse and J. Furthmüller, "Efficiency of ab-initio total energy calculations for metals and semiconductors using a plane-wave basis set," Computational Materials Science, vol. 6, no. 1, pp. 15-50, 1996.

[39] P. E. Blöchl, "Projector augmented-wave method," Physical Review. B, Condensed Matter, vol. 50, pp. 17953-17979, 1994.

[40] G. Kresse and D. Joubert, "From ultrasoft pseudopotentials to the projector augmented-wave method," Physical Review B, vol. 59, Article ID 1758, 1999.

[41] H. J. Monkhorst and J. D. Pack, "Special points for Brillouin-zone integrations," Physical Review B, vol. 13, Article ID 5188, 1976.

[42] J. P. Perdew, K. Burke, and M. Ernzerhof, "Generalized gradient approximation made simple," Physical Review Letters, vol. 77, pp. 3865-3868, 1996.

[43] G. Henkelman, B. P. Uberuaga, and H. Jónsson, “A climbing image nudged elastic band method for finding saddle points and minimum energy paths," The Journal of Chemical Physics, vol. 113, no. 22, pp. 9901-9904, 2000.

[44] G. Mills, H. Jónsson, and G. K. Schenter, "Reversible work transition state theory: application to dissociative adsorption of hydrogen," Surface Science, vol. 324, no. 2-3, pp. 305-337, 1995.

[45] L. F. Mattheiss and D. R. Hamann, "Linear augmented-planewave calculation of the structural properties of bulk $\mathrm{Cr}, \mathrm{Mo}$, and W," Physical Review B, vol. 33, no. 2, pp. 823-840, 1986.

[46] A. Zunger and M. L. Cohen, "Self-consistent pseudopotential calculation of the bulk properties of Mo and W," Physical Review B, vol. 19, Article ID 568, 1979.

[47] N. V. Petrova and I. N. Yakovkin, "Density-functional and Monte Carlo study of O/Mo (110): structures and desorption," Physical Review B, vol. 76, Article ID 205401, 2007.

[48] Y. G. Zhou, X. T. Zu, J. L. Nie, and H. Y. Xiao, "Firstprinciples study of sulfur adsorption on Mo(1 110$)$," Chemical Physics, vol. 353, pp. pp109-113, 2008.

[49] B. Kohler, P. Ruggerone, and M. Scheffler, "Ab initio study of the anomalies in the He-atom-scattering spectra of $\mathrm{H}$ / Mo(110) and H/W(110)," Physical Review B, vol. 56, Article ID 13503, 1997.

[50] K. Kośmider, A. Krupski, P. Jelínek, and L. Jurczyszyn, "Atomic and electronic properties of the $\mathrm{Pb} / \mathrm{Mo}(110)$ adsorption system," Physical Review B, vol. 80, Article ID 115424, 2009. 
[51] M. Methfessel, D. Hennig, and M. Scheffler, "Trends of the surface relaxations, surface energies, and work functions of the $4 \mathrm{~d}$ transition metals," Physical Review. B, Condensed Matter, vol. 46, pp. 4816-4829, 1992.

[52] H. L. Skriver and N. M. Rosengaard, "Surface energy and work function of elemental metals," Physical Review B, vol. 46, no. 11 , pp. 7157-7168, 1992.

[53] M. Arnold, S. Sologub, G. Hupfauer et al., "Leed structure analyses of the clean and fully hydrogen-covered W(110) and Mo(110) surfaces," Surface Review and Letters, vol. 4, no. 6, pp. 1291-1295, 1997.

[54] H. Luo, J. Cai, X. Tao, and M. Tan, "Adsorption and dissociation of H2S on $\mathrm{Mo}(100)$ surface by first-principles study," Applied Surface Science, vol. 292, pp. 328-335, 2014.

[55] H. Luo, J. Cai, X. Tao, and M. Tan, "First-principles study of $\mathrm{H} 2 \mathrm{~S}$ adsorption and dissociation on $\operatorname{Mo}\left(\begin{array}{lll}1 & 1 & 0\end{array}\right)$," Computational Materials Science, vol. 101, pp. 47-55, 2015. 